\title{
The Principle of Fairness and Political Obligation
}

George Klosko

Rowman and Littlefield, Lanham, MD, 2004, xxvii $+204 p p$.

ISBN: 0-7425-3375-1.

Contemporary Political Theory (2005) 4, 220-223. doi:10.1057/palgrave.cpt.9300199

George Klosko's well-known book on political obligation, first published in 1992, now appears in a 'new edition' with a new Introduction. The text is otherwise unchanged. I think this is a pity, for, while Klosko's main ideas are quite persuasive, his exposition of them suffers from a number of confusions and contradictions that could have been addressed.

Political obligation, roughly speaking, is the moral obligation of individuals (and other private agents) to obey political authority - to obey the laws of the state, to pay taxes, and so on. Corresponding to this obligation is the right of state agencies to demand and if necessary enforce such obedience - this is the authority of the state. Anarchists, of course, deny that either political obligation or state authority (in the moral sense) exist, so Klosko naturally gives some attention to their views - more specifically, those of so-called 'philosophical anarchists' such as Robert P. Wolff and A. John Simmons. Unlike classical anarchists, 'philosophical' ones don't want to abolish the state, but they do reject political obligation and state authority.

Does 'philosophical' anarchism make sense? The question arises because philosophical anarchists accept (even want) law, and do not assert any unlimited right to break it. That is, individuals should obey the law, if but only if they judge it right to do so. On the other hand, Klosko, as a believer in political obligation, need not and does not assert an absolute obligation to obey. Our political obligation may be outweighed by a stronger conflicting obligation - if, for example, a law violates a fundamental right (p. 66). As Klosko puts it, political obligations are prima facie, not 'conclusive'. The difference between Klosko and the philosophical anarchist, presumably, is this: while both will weigh up the moral case for and against obeying a particular law, Klosko, unlike the philosophical anarchist, will give some weight to political obligation. The political anarchist in the end acts just as he would if the law didn't exist (though one wonders, then, why he wants it to exist), or at most treats it as an opinion like any other opinion, not as a law.

Another complicating issue for the philosophical anarchist is the fact that the existence of the state can radically alter the moral situation of the individual. This is obvious from what lawyers call mala prohibita (contrasted with mala in se), that is, actions that would not be wrong were they not so declared by law - for example, driving on the right in the UK, or driving the wrong way in a one-way street, or failing to pay one's due taxes. Presumably the philosophical 
anarchist recognizes his moral obligation to obey the rule of the road and to pay his just taxes. But then he does not claim freedom to act just as he would if the law did not exist - he accepts that the state can create moral obligation. Should such a person be called an anarchist, of any stripe?

One main reason for state taxation is to finance the supply of public goods: for Klosko it is this state function that is the main ground of political obligation. A good is 'public' if it provides benefits for all members of a group, and cannot be provided for some without being provided for all (is 'non-excludable'). The principle of fairness suggests that every beneficiary should contribute their share of the good's cost, even although the good could often be provided without any contribution from some members of the group (the non-contributors being 'free riders'). The temptation to be a free rider, of course, jeopardizes the provision of the good, and justifies the state in coercing beneficiaries to 'cooperate'. Klosko's argument is that beneficiaries have a moral obligation to cooperate, and hence a political obligation to obey a state which demands cooperation. Among the standard state-provided public goods are national defence, internal order and security, measures of public health, and so on. Klosko's argument implies a political obligation to pay the taxes necessary to finance such goods; also, since maintaining internal order and security entails enactment and enforcement of laws, political obligation extends to obeying those laws.

The principle of fairness (like much else in Klosko's book) has a Rawlsian ancestry. As Klosko quotes Rawls, the idea is that 'when a number of persons engage in a mutually advantageous cooperative venture [and] restrict their liberty in ways necessary to yield advantages for all, those who have submitted to these restrictions have a right to similar acquiescence [from] those who have benefited from their submission' (p. 33). Yet Rawls declined to found political obligation on this principle, because of a distinction he made between an obligation and a duty. As Klosko puts it, an obligation is generated by some action, by which the agent creates the correlative right of another agent against him, while duties typically derive from particular social positions, or else are owed by all persons ('natural duties'). Rawls, therefore, preferred to derive a duty to obey legitimate authorities from a natural duty to support just institutions, rather than speak of political obligation (p. 12). Unfortunately, Klosko contradicts himself on this issue (or at best is unclear). He accepts the duty/obligation distinction, yet rejects Carole Pateman's view that obligation must be 'self-assumed' by a voluntary action (p. 10); and correspondingly stresses that enjoyment of benefit (without any action or even intention) suffices to create political obligation (pp. 41-42).

Klosko's view of political obligation is more complex than indicated so far. As he says, the principle of fairness generates political obligation for any beneficiary of a state-supplied public good, but on three conditions: (1) the good is worth its cost to the recipient; (2) it is a 'presumptive' good, which 
means that it is 'indispensable' to every member of the community for an acceptable life; and (3) the benefits and burdens it involves are fairly distributed. Conditions (2) and (3) are problematic. I believe that condition (2) is too strict (Klosko himself seems to waver, suggesting on p. 49 that 'significant' benefit suffices for obligation). Generally, he is not very consistent about conditions (2) and (3), for he speaks of political obligation as being a 'good reason to obey the law just because it is the law', that is, regardless of the conditions (the quote, from p. 3, is not an isolated example). Again (p. 64), he is confused as to whether fairness obligations arising from cooperative schemes are nullified ('dissolved') by (serious) unfairness in their organization, or whether there is still a prima facie though not a conclusive obligation (he should of course say there is no obligation in such a case).

What constitutes a fair distribution of benefits and burdens involved in the provision of public goods is, of course, highly controversial, as Klosko recognizes. However, his solution to the problem is not satisfactory. His idea is that several (not all) such distributions are 'defensible': to generate fairness obligations some defensible distribution must be chosen by a fair, that is democratic decision-procedure (for instance, pp. 65, 120). In other words, to Klosko only democratic governments generate political obligation, which means that historically political obligation has been a great rarity. That this is highly counter-intuitive might not be a crippling objection, but for the fact that Klosko also tells us that an adequate theory must 'address' (that is, explain) the feelings of political obligation that (he says) 'most people' feel they have to the laws of their societies (pp. 5, 21). (It is no answer to this objection - only a source of confusion - that Klosko at one point mentions the possibility of other theories of political obligation based on 'nonliberal' principles.) As all this suggests, Klosko can at times be unduly complacent about the moral worthiness of governments, despite his apparently strict conditions for political obligation. Here we have another unresolved inconsistency.

I mentioned earlier that Klosko's second condition of political obligation, that the public good generating it must be 'indispensable' for all, is too strict. Again, Klosko recognizes a problem here, but fails to solve it. The problem is, obviously, that the range of genuinely indispensable public goods is too limited (possibly dictating a Nozickian minimal state) - so Klosko seeks to extend it to include some 'discretionary' (beneficial but not indispensable) goods as well - for example, 'transportation and communication facilities... clean water... pubic education' ( $p$. 87-88), said to be essential for the provision of 'presumptive' (indispensable) goods. If so, they are surely not discretionary; however, arguably they are not, strictly, indispensable. But it doesn't really matter - I see no reason why they need be, so long as they satisfy Klosko's two other conditions (are worth their cost to all, and are financed and organized fairly). Klosko here creates unnecessary difficulties for himself. 
Indeed, even the first condition is unnecessary, as Klosko himself recognizes, because he wants to justify state redistribution in favour of the needy. He thus acknowledges that his public goods-based argument for political obligation needs to be supplemented by another, based on a principle variously called the 'samaritanism' principle or the duty of mutual aid. Oddly, Klosko says these are natural duties of justice, yet claims they are needed to supplement the fairness principle (p. 91). Surely they are part of it (as Rawls argues). Klosko is wrong to think that the fairness principle applies only to public goods.

Michael Lessnoff

University of Glasgow, UK.

\author{
Regulating Intimacy: A New Legal Paradigm \\ Jean L. Cohen \\ Princeton University Press, Princeton, 2002, xiv $+290 p p$. \\ ISBN: 0-691-11789-6.
}

Contemporary Political Theory (2005) 4, 223-225. doi:10.1057/palgrave.cpt.9300200

In this interesting and well-argued book, Jean Cohen addresses the problem that freedom and equality are often positioned as being in opposition. She wants to move beyond both liberal and welfare paradigms in the regulation of reproductive rights, sexual harassment issues and gay rights, by focusing upon the meaning of 'privacy' and by advocating 'reflexive law'. While her discussion is clearly situated within the US, it does raise theoretical issues that are relevant to readers in different legal jurisdictions.

In the first chapter, Cohen considers how the right to use contraception and to have an abortion have developed in US law as 'privacy rights'. The courts decided that police should not have the power to check to see if a couple (initially a married couple) were using contraception and so contraception was legalized by employing a framework of 'privacy'. This approach initially appears to do no more than re-state a liberal public/private divide, in which the state does not interfere with what happens in the 'private' domestic sphere - the traditional logic that left men free to abuse women in the home. However, in the 1960s, US law transposed this traditional notion of privacy into a doctrine that singled out the individual rather than the family unit, 'as the bearer of autonomy insulated from publicly created norms' (p. 39). While this development has been criticized by communitarians as presupposing an image of ourselves as atomistic 'possessive individuals', it is a development that Cohen seeks to defend. She argues that the communitarians' argument employs a category mistake; that it is unnecessary to presume any view of what it is to be a self in order to decide upon the norms and laws relating to privacy. 